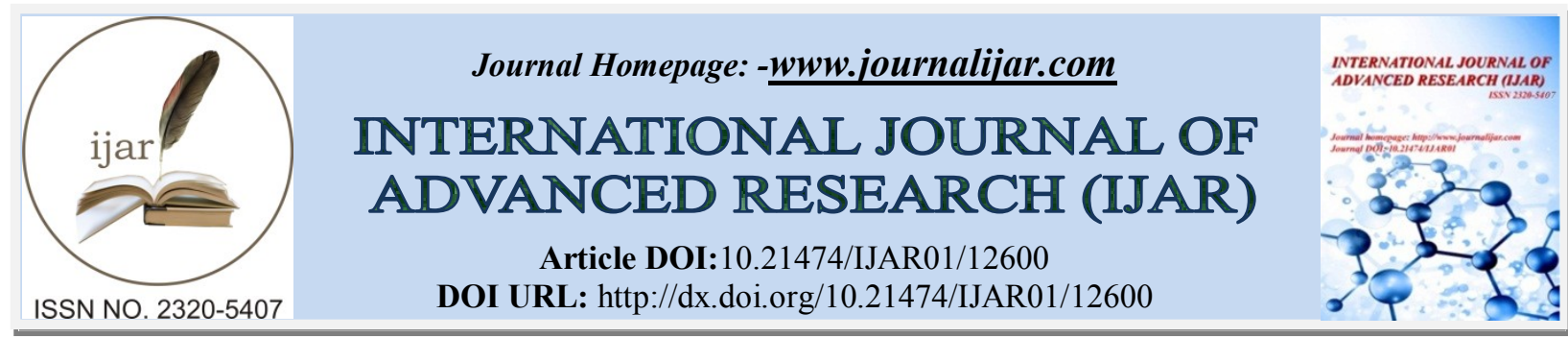

RESEARCH ARTICLE

\title{
EFFECTS OF VARIETIES AND BLANCHING TEMPERATURES ON THE FUNCTIONAL AND NUTRITIONAL QUALITIES OF PLANTAIN FLOUR
}

\author{
Patience T.K. ${ }^{1}$, Nwachukwu V.C. ${ }^{1}$, Inchikida B.M. ${ }^{1}$, Sharinya J.T. ${ }^{1}$ and Fatima F.K. ${ }^{2}$ \\ 1. Nigeria Natural Medicine Development Agency. \\ 2. Department of Agriculture Engineering and Biomolecular Study Federal University of Technology, Minna.
}

\section{Manuscript Info}

.1........................

Manuscript History

Received: 20 January 2021

Final Accepted: 24 February 2021

Published: March 2021

Key words:-

Blanching Temperature, Functional and

Nutritional Qualities, Plantain Flour

\section{Abstract}

A study was carried out on effects of varieties and blanching temperatures on the functional and nutritional qualities of plantain flour. Seven (7) bunches of plantain labelled O35, O48.2, O61.6, O75, P35, P55 and P75 were collected within Minna metropolis. After washing, peeling, slicing, Blanching, Drying and Milling, for nutritional qualities, O75 has the highest moisture content of 16.3, followed by O35 that has 10.6 while P75 has the least of 3.1. For ash content O61.6 has the highest of 3.2, followed by $\mathrm{O} 48.2$ and $\mathrm{O} 75$ that has 2.0 and P55 has the least of 0.5. For crude fat O35 has the highest of 47.0 followed by O75 that has 37.5 while O61.6 and P75 has the least of 34.5. For crude protein, P55 has the highest of 10.68, followed by $\mathrm{O} 48.2$ and $\mathrm{O} 75$ with 8.58 respectively while $\mathrm{P} 75$ has the least of 5.08. For crude fibre O48.2 has the highest of 28.5, followed by $\mathrm{O} 75$ that has 14.5 while O61.6 has the least of 3.0. For carbohydrate, P75 has the highest of 48.32 , followed by O61.6 that has 43.05 while $\mathrm{O} 48.2$ has the least of 17.62. For functional qualities, P75 has the highest bulk density of $0.8 \mathrm{~g} / \mathrm{ml}$ followed by P35 that has $0.77 \mathrm{~g} / \mathrm{ml}$ while $\mathrm{O} 75$ has the least of $0.51 \mathrm{~g} / \mathrm{ml}$. For WAC P75 has the highest of $28 \%$, followed by P55 that has $22 \%$ while O35 has the least of $10 \%$. For OAC, P75 has the highest of $24 \%$, followed by P35 with P35 with $20 \%$ while O35 and O61.6 with the lowest of $16 \%$ each. For foam capacity, O35 has the highest of $16.6 \%$, followed by $\mathrm{O} 75$ with $12 \%$ while P55 has the least of $1.8 \%$. For Emulsion capacity, $\mathrm{O} 75$ has the highest of $38.6 \%$ followed by P35 with $31.6 \%$ while $\mathrm{O} 48.2$ has the least of $25.73 \%$. The ogeda flour had higher moisture content, ash content, fat, fiber. While the panbolabola flour had a higher protein, carbohydrate for the nutritional properties.

Copy Right, IJAR, 2021,. All rights reserved.

\section{Introduction:-}

Plantains (Musa spp., AAB genome) are plants producing fruits that remainstarchy at maturity (Marriot and Lancaster, 1983; Robinson, 1996) and need processingbefore consumption. Plantain production in Africa is estimated at more than $50 \%$ ofworldwide production (FAO, 1990). The majority (82\%) of plantains in Africa areproduced in the area stretching from the lowlands of Guinea and Liberia to the centralbasin of the Democratic Republic of Congo. West and Central Africa contribute 61 and $21 \%$, respectively (FAO, 1986). It is estimated that about 70 million people in West andCentral Africa derive more than $25 \%$ of their carbohydrates from plantains, 
making themone of the most important sources of food energy throughout the African lowland humidforest zone (Swennen, 1990).

Nigeria is one of the largest plantains producing countries in the world (FAO,2006). Despite its prominence, Nigeria does not feature among plantain exporting nationsbecause it produces more for local consumption than for export. National per capitaconsumption figures show its importance relative to other starch staples (FAO, 1986).However, these figures do not show regional reliance, which is often very important forhighly perishable crops that are usually consumed in or near areas of production. The consumption of plantain has risen tremendously in Nigeria in recent yearsbecause of the rapidly increasing urbanization and the great demand for easy andconvenient foods by the nonfarming urban populations. Besides being the staple formany people in more humid regions, plantain is a delicacy and favored snack for peopleeven in other ecologies. A growing industry, mainly plantain chips, is believed to beresponsible for the high demand being experienced now in the country. This studyreviews the trend of plantain production, its problems and prospects in Nigeria in the lasttwo decades.

Plantains are good bases of potassium and nutritive fiber. They also comprise of vitamins A (83 micrograms), vitamin C (27mg), vitamin B2, vitamin B6 (0.44mg) and Magnesium (55mg). The juice that oozes from peeling the plant can tinge clothing and hands, and the stain can be very difficult to remove. Banana plantain meal is an important food source that has the following constituents: water (10.62\%), fat $(1.15 \%)$, carbohydrates $(81.67 \%)$ more than $2 / 3$ starch, fiber $(1.15 \%)$, phosphates $(0.26 \%), 1.60 \%$ sugar, and other salts. The primary sugar is sucrose (Jacquelyn,2016). Blanching means a short-range heat treatment $\left(70-100{ }^{\circ} \mathrm{C}\right)$ that is applied to vegetables preceding to more processing with the objective of enhancing both safety and quality attributes. Several reactions occur. Enzymes are deactivated (e.g., polyphenol oxidase) to prevent discoloration also destruction of surface micro flora on vegetables and the enhancement of the color, texture and keeping the quality of vegetable products (Lindhauer, 2003). Therefore, this work was aimed at determining the effects of blanching temperatures on varieties of unripe plantain and the Nutritional and Functional properties of the plantain flour.

\section{Materials And Methods:-}

\section{Plant Collection:}

Seven (7) (O35, O48.2, O61.6, O75, P35, P55 and P75) bunches of Unriped plantains were collected within Minna metropolis and brought to the Crop Processing and Storage Laboratory in the Department of Agricultural and Bioresources Engineering, Federal University of Technology, Minna (Niger state) for further processes.

\section{Material Preparation:}

Unit operations are the step by step processes carried out to produce plantain flour.

1. Washing: after harvesting this plantain, it may contain some impurities on it such as mud or sand. Clean water is use to wash these impurities.

2. Peeling: peeling is essential for making high quality plantain flour, the plantain was hand peeled.

3. Slicing: the plantain was manually sliced into pieces of about $2 \mathrm{~mm}$ thickness.

4. Blanching: the already washed plantain is placed in hot water at $35^{\circ} \mathrm{C}, 48.2^{\circ} \mathrm{C}, 55^{\circ} \mathrm{C}, 61.6^{\circ} \mathrm{C}, 75^{\circ} \mathrm{C}$ temperatures to destroy the enzymes and bacteria faster, allowing beneficial benefits of plantain product to survive the process of flour production.

5. Drying: the use of a Gallen Kamp (oven 300 plus series) oven dryer is employed at $70{ }^{\circ} \mathrm{c}$ for 24 hours. This is done to reduce the moisture contained in the plantain to attain a flakes state which could be milled.

6. Milling: milling machine is used to bring the plantain to flour which was then sieved to produce fine powder which is a ready form for the analysis to be carried out. The flour is then stored in polyethylene bags and labelled with codes and stored at room temperature.

\section{Determination of Nutritional Properties: Determination of Moisture Content:}

$5.0 \mathrm{~g}$ of powder was weighed and moved into a formerly weighed crucible. The crucible was then positioned into the electric drying oven at about $105^{\circ} \mathrm{c}$ for 2 hours. They crucible containing dried sample was removed and placed in a desiccator to cool. The cooled crucible was weighed. The weight loss after drying was then evaluated as percentage moisture content (AOAC, 1990).

$$
\% \text { moisturecontent }=\frac{w 1-w 2}{w 3} \times 100
$$




\section{Determination of Ash Content:}

$2 \mathrm{~g}$ of sample was weighed into a crucible of known weight and placed in a muffled furnace for about 2 hours. The crucibles were cooled and weighed again. The loss in weight was then calculated as percentage ash content of the sample (AOAC, 1990).

$$
\% \text { ashcontent }=\frac{\text { weightofash }}{\text { weightof sample }} \times 100
$$

\section{Determination of Carbohydrate:}

The carbohydrate content was determined by calculation using the difference method:

$\%$ carbohydarte $=100-\%($ moisturecontent - crudeprotein - crudefat - crudefiber ashcontent

\section{Determination of Crude Fibre:}

A defatted sample of $2.0 \mathrm{~g}$ was used. The residue was boiled in acid $\left(\mathrm{H}_{2} \mathrm{SO}_{4}\right)$ with concentration of $0.25 \mathrm{~mol}$ and heated using a hot plate for 30 minutes and then filtered through cheese cloth and washed clean with distilled water, this is done till sample is no longer acidic. The same sample is then boiled with alkaline $(\mathrm{NaOH})$ with concentration of $0.25 \mathrm{~mol}$ and heated using a hot plate for 30 minutes and washed with distilled water.The sample is then oven dried. The dried sample is then put in a crucible and heated until it turns to ash. The weights are taken and use to compute percentage crude fiber using:

$$
\% \text { crudefiber }=\frac{\text { weightofash }}{\text { weightofsample }} \times 100
$$

\section{Determination of Crude Fat:}

$2 \mathrm{~g}$ of sample is put in filter paper which is stapled for proper closure. A round bottom flask to be used was weighed. Petroleum ether was added to the flask and the Soxhlet apparatus was assembled. A condense was connected to the Soxhlet extractor and reflux for 6 hours on low heat. The flask was removed and evaporated at steam bath. The flask with the fat was heated for approximately $30 \mathrm{mins}$ in an oven. The flask and its contents were cooled to room temperature in a desiccator after which it was weighed and percentage fat was calculated using:

$$
\% \text { crude fat }=\frac{\text { weightofoil }(\text { fat })}{\text { weightofsample }} \times 100 \%
$$

\section{Determination of Crude Protein:}

The nitrogen value of the samples was determined by micro kjeldhal method. The nitrogen valve obtained was multiplied by 6.25 to convert it to crude protein.

$$
\begin{aligned}
\% \text { nitrogen } & =\frac{\text { titrevalue } \times \text { molarityof sulphuricacid } \times 0.0014 \times 50}{5} \times 100 \\
\% \text { crudeprotein } & =\% \text { nitrogen } \times 6.25
\end{aligned}
$$

\section{Determination of Functional Properties:} Determination of Water Absorption Capacity:

One gram of sample and $10 \mathrm{ml}$ of distilled water was mixed and emptied into a centrifuge bottle and stirred. This is allowed to stand for 30 minutes and placed into a centrifuge, setting it to 2000rpm for 15 minutes. This then then allowed a time line between 5 minutes for separation. Then decantation was carried out and the amount of water remaining was measured.

\section{Determination of Oil Absorption Capacity:}

One gram of sample and olive oil with specific gravity 0.9092 was mixed and poured into a centrifuge bottle and stirred. This is allowed to stir for 30 minutes and placed into a centrifuge, setting it to 2000rpm for 15 minutes. This then then allowed a time line between 5 minutes for separation. Then decantation was carried out and the amount of oil remaining was measured using a measuring cylinder. 


\section{Determination of Least Gelation:}

The least gelation concentration was calculated using a modified method of Coffman and Garcia (1977). The flour dispersions $(2,4,6,8,10 \%)$ were prepared in $10 \mathrm{ml}$ distilled water was heated at $90^{\circ} \mathrm{c}$ for 1 hour in water bath. The contents were cooled and kept for 22 hours.

\section{Determination of Emulsion Capacity:}

$2.0 \mathrm{~g}$ of sample was dispersed in $25 \mathrm{ml}$ distilled water and $25 \mathrm{ml}$ vegetable oil added. The $50 \mathrm{ml}$ mixture was emulsified at high speed for 1 minute. The emulsions were filled into centrifuge tubes and centrifuged for 5 minutes at $1300 \times 6 \mathrm{rpm}$. Percentage emulsion capacity was calculated using:

$$
\% \text { emulsion }=\frac{\text { heightofemulsifier }}{\text { heightof wholesolutioncentrifugebottle }} \times 100
$$

\section{Determination of Foam Capacity and Stability:}

The method of AOAC (1984) was used. One gram of each sample of flour was blended with $50 \mathrm{ml}$ of distilled water in a blender and whipped for 5 mins. The mixture was poured into a $250 \mathrm{ml}$ measuring cylinder and the volume was recorded after approximately 30 seconds. Foaming capacity is calculated using the formula:

$$
\text { foamcapacity } \frac{\text { volumeafterwhipping - volumebeforewhipping }}{\text { volumeafterwhipping }}
$$

The foam was recorded at an interval of $(15,30,60$ and 120 seconds) after whipping to determine the foam stability using the formula:

$$
\text { foamstability } \frac{\text { foamvolumeaftertime }}{\text { initialfoamvolume }} \times 100
$$

\section{Determination of Bulk Density:}

The method of Onwuka (2005) which is a modification of AOAC (1984) was used. A 100ml capacity graduated measuring cylinder was weighed and recorded. The flour sample was gently placed in the measuring cylinder to the $10 \mathrm{ml}$ graduation. The cylinder is gently tapped on the table several times until there is no further diminution of sample level. The bulk density is then calculated using:

$$
\text { bulkdensity } \frac{\text { weightofsample }}{\text { finalvolumeof sampleaftertapping }}
$$

\section{Statistical Analysis:}

The data obtained was subjected to analysis of variance (ANOVA) and significance difference were reported at $95 \%$ confidence level using factorial (characterization).

\section{Results and Discussions:-}

The nutritional and functional properties were determined to investigate the effect of blanching temperatures on the value and characteristics of the plantain flour. The results of the nutritional properties of the varieties of plantain is presented in table 1

Table 1:- Nutritional properties of plantain flour.

\begin{tabular}{|l|c|c|c|c|c|c|}
\hline Samples & $\begin{array}{c}\text { Moisture } \\
\text { content (\%) }\end{array}$ & $\begin{array}{c}\text { Ash content } \\
(\%)\end{array}$ & $\begin{array}{c}\text { Crude fat } \\
(\%)\end{array}$ & $\begin{array}{c}\text { Crude } \\
\text { protein (\%) }\end{array}$ & $\begin{array}{c}\text { Crude fiber } \\
(\%)\end{array}$ & Carbohydrate (\%) \\
\hline & & & & & & \\
\hline O35 & 10.6 & 1.99 & 47 & 7 & 4 & 29.41 \\
\hline O48.2 & 7.3 & 2 & 36 & 8.58 & 28.5 & 17.62 \\
\hline O61.6 & 8.2 & 3.2 & 34.5 & 8.05 & 3 & 43.05 \\
\hline O75 & 16.3 & 2 & 37.5 & 8.58 & 14.5 & 21.12 \\
\hline & & & & & & \\
\hline P35 & 4.8 & 1.49 & 35 & 7.18 & 9.5 & 42.03 \\
\hline P55 & 7.5 & 0.5 & 35 & 10.68 & 4 & 42.32 \\
\hline P75 & 3.1 & 2 & 34.5 & 5.08 & 7 & 48.32 \\
\hline
\end{tabular}


KEY: O35- ogeda blanched at $35^{\circ} \mathrm{c}, \mathrm{O} 48.2$ - ogeda blanched at $48.2^{\circ} \mathrm{c}$, O61.6- ogeda blanched at $61.6^{\circ} \mathrm{c}$, O 75 - ogeda blanched at $75^{\circ} \mathrm{c}$, P35- panbolabola blanched at $35^{\circ} \mathrm{c}$, P55- panbolabola blanched at $55^{\circ} \mathrm{c}$, P75- panbolabola blanched at $75^{\circ} \mathrm{c}$. The results of the functional properties are presented in table 2

Table 2:- Functional Properties of Plantain flour.

\begin{tabular}{|l|c|c|c|c|c|c|}
\hline Sample & $\begin{array}{c}\text { Bulk density } \\
(\mathrm{g} / \mathrm{ml})\end{array}$ & $\begin{array}{c}\text { WAC } \\
(\%)\end{array}$ & $\begin{array}{c}\text { OAC } \\
(\%)\end{array}$ & $\begin{array}{c}\text { Foam } \\
\text { capacity (\%) }\end{array}$ & $\begin{array}{c}\text { Emulsion } \\
\text { capacity } \\
(\%)\end{array}$ & Least gelation \\
\hline O35 & 0.63 & 10 & 16 & 16.6 & 30.2 & 6 \\
\hline O48.2 & 0.59 & 14 & 18 & 8.4 & 25.73 & - \\
\hline O61.6 & 0.61 & 13 & 16 & 8.8 & 28.8 & 4 \\
\hline O75 & 0.51 & 14 & 18 & 12 & 38.6 & 8 \\
\hline P35 & 0.77 & 16 & 20 & 8 & 31.6 & - \\
\hline P55 & 0.74 & 22 & 18 & 1.8 & 28.8 & - \\
\hline P75 & 0.8 & 28 & 24 & 2 & 33 & 4 \\
\hline
\end{tabular}

\section{Discussion of Results:-}

The low moisture content of the variety panbolabola would enhance its storage ability by avoiding the growth of mould and some biochemical reactions, the moisture content of panbolabola was within acceptable limit of within $10 \%$ for long storage of flour (Singh et al., 2005) making the panbolabola flour have a better storage shelf life than the ogeda flour. According to (Haard and Chism 1996), low moisture content of flour will in the end extend the shelf life of the product produce from the flour because moisture content and water activity have been reported to have effects on the keeping ability and storage of foods (Eke-Ejiofor and Owuno, 2012). Ogeda plantain flour had its lowest value when blanched at $35^{\circ} \mathrm{C}$ and its highest value at $61.6^{\circ} \mathrm{C}$ while the panbolabola had its lowest value at $0.5 \%$ and its highest value at $2 \%$. This is contrary to the report of Oluwalana (2011) who stated that an increase in blanching temperature leads to a decrease in ash content of flour. Table 4.1 shows that the crude protein for ogeda flour ranges from $7 \%$ to $8.58 \%$ and panbolabola flour ranges from $5.08 \% 10.68 \%$. Generally, plantain has been reported to contain between 3.15 and $4.61 \%$ protein (Adenijiet al., 2007 and Eleazuet al., 2010).Emulsifying capacity which is the ability of protein to emulsify oil, it indicates the maximum amount of oil that can be emulsified by protein dispersion (Enujuighaet al., 2003).

\section{Conclusion:-}

This study has characterized the nutritional and functional properties of ogeda and panbolabola flours. The ogeda flour had higher moisture content, ash content, fat, fiber. While the panbolabola flour had a higher protein, carbohydrate for the nutritional properties. The blanching temperature provided a better flour from the panbolabola variety with a better shelf life due to its low moisture content compared to the ogeda flour. The ash content of ogeda flour is higer than that of the panbolabola thereby making it a better source of mineral content of food.

\section{References:-}

1. Adeniji, A.A.A, Usman, J.M., Abiola, I.O and Akinyemi, S.O.S. (2007). Problems andprospects of plantain marketing in Ibadan. Proc. 22nd Annual Conference ofHorticultural Society of Nigeria. Ibanda, Nigeria 3-6, September. p.142-145.

2. AOAC International, (1990). Official methods of analyses of the association of official analytical chemists. $15^{\text {th }}$ ed. AOAC International, Arlington, Virginia, USA

3. AOAC International, (1984). Official methods of analyses of the association of official analytical chemists.

4. Coffman, C.V and Garcia, V.V (1977). Functional properties and amino acid content of a protein isolate from mung bean flour. Journal of Food Technology. (3) 19- 22.

5. Eke- Ejiofor, J., and Owuno, F. (2012). Functional and pasting properties of wheat/three-leaved yam (Dioscoreadumentorum) composite flour blend. Global Research Journal of Agricultural and Biological Sciences, 3, 330-335.

6. Eleazu, A. M., Bayeri, K.P. and Nwachukwu, I. 2003. Storage methods influenced occurrence and severity of crown rot and anthracnose diseases on plantain (Musa spp. ABB) fruitsduring storage and post storage. p.201204. In: A.S. Fasina, A.O. Olufolaji and V.C.Umeh (eds.), Proceeding of the 21 st Annual Conference of the Horticultural Society ofNigeria. Ess-Jay Business and Publishing Centre, Lagos. 
7. Enujuigha V. N., Badejo A. A., Iyiola S. O., Oluwamukomi M. O. (2003). Effect of germination on the nutritional and functional properties of African oil bean seed flour. J. Food, Agricultural Environment, 1 (3and 4): $72-75$.

8. F.A.O. (1986). Roots, tubers, plantains and bananas in animal feeding (D. Machin and S. Nyvold, editors).

9. F. A. O. (1990). Production Yearbook 1990. FAO, Rome.

10. F. A. O. (2006). Production Yearbook 2004. FAO, Rome.

11. Haard, N.F. and G. W. Chism. (1996). Characteristics of edible plant tissues, Food Chemistry. New York: Marcel Dekker, Inc. pp. 943-1001.

12. Jacquelyn C. (2016). Plantains: Nutrition Facts and Health Benefits; medically reviewed by Peggy Pletcher, MS, RD, LD, CDE, october7, 2016

13. Lindhauer, M.G. (2003). In Encyclopedia of Food Sciences and Nutrition (Second Edition).

14. Marriot, J. And Lancaster, S.K. (1983). Starch and sugar transformations during ripening of plantains and bananas. J. Sci. Food Agric., 32, 1021-1026.

15. Oluwalana, I.B., Oluwamukomi, M.O., Fagbemi,T.N., and Oluwafemi, G.I. (2011). Effects of temperature and period of blanching on the pasting and functional properties of plantain (Musa parasidiaca) flour. Journal of Stored Products and Postharvest Research, 2, 164-169.

16. Onwuka, G. I. (2005). Food Analysis and Instrumentation: Theory and Practice. Lagos, Nigeria: Naphtali Prints.

17. Singh, N., Sandhu, K. S., and Kaur, M. (2005). Physicochemical properties including granular morphology, amylose content, swelling and solubility, thermal and pasting properties of starch from normal, waxy, high amylose and sugary corn. Progress in Food Biopolymer Research, 1, 43-54.

18. Robinson, J.C. (1996). Bananas and Plantains. CAB International, Wallington.

19. Swennen, R. (1990). Plantain Cultivation under West African Conditions. A ReferenceManual. Amarin Printing Group Co., Bangkok. 